\title{
La narrativa del tango en el teatro: dos estéticas
}

Adriana M. Carrión e María Rosa Petruccelli

Universidad de Buenos Aires

\section{Introducción}

De todas las imágenes que propone el nuevo siglo, nosotras preferimos seguir trabajando con una proveniente del anterior: la del tango y su manifestación en el teatro.

Reflexionaremos pues acerca de dos puestas en escena que tienen como motivo la danza del tango. El subtítulo de una de estas puestas -"guarda con el tango"- nos advierte, nos insinúa que las cosas no son tan simples como se presentan a primera vista. ¿Qué tendrá esta danza, ya que ella es el motivo que, en cada una de las obras, provoca pasiones tan fuertes que hacen que el juego sea a vida o muerte, o que se creen nudos vitales, insólitos o no, en los que, por ejemplo, poesía y erotismo se incluyen mutuamente? Arte y amor parecen no poder excluirse de la vida cotidiana, así como tampoco la lucha entre machos por la posesión de una hembra.

¿Cómo se narra en cada puesta en escena el triángulo amoroso? ¿Con qué imágenes? ¿A qué siglo, o mejor dicho, a qué período estético pertenece esta narrativa del tango en la actualidad de nuestro teatro?

En este trabajo, nos interesa comparar y analizar dos puestas en escena recientes: Metejón, guarda con el tango, de Ricardo Halac, con dirección de Luis Luque (estrenada en la Sala Gandhi, en el año 2000) y Che Madam de Carlos Pais y Américo Torchelli, con dirección de Osvaldo Bonet (estrenada en el Teatro Nacional Cervantes, en el año 2001) que presentan idéntica estructura dramática pero enfocadas desde estéticas diferentes: la posmodernidad y el realismo asainetado. Conceptos y/o definiciones sobre los cuales no vamos a polemizar, sino simplemente tomar algunas de las que consideramos son sus características. Tampoco lo haremos sobre otros conceptos como el de ritualidad e hiperrealismo a los cuales recurriremos en su momento.

El tema que nos interesa analizar y ejemplificar transita, por un lado, entre una reescritura y recontextualización del modelo melodramático propuesto por nuestra canción popular urbana. Y por otro lado, el cruce o desplazamiento de fronteras e hibridación de los modelos genéricos teatrales provenientes de 
esta misma cultura popular, derivaciones del melodrama, el sainete y el grotesco criollos.

El tango canción que nace en la segunda década del siglo XX ("Mi noche triste" de Pascual Contursi y Samuel Castriota, estrenado por Carlos Gardel en 1917) según Rivera y Ford: “... da comienzo a la era de la letra de tangos tal cual hoy la conocemos. Contursi canoniza en el tango el ciclo del varón que se lamenta por el abandono de la compañera. Al hacerlo afirma la estructura anecdótica del tango, que relata con lenguaje cotidiano, vivencializador y concreto"1.

El triángulo amoroso, implícito o explícito, se presenta ya como una de las estructuras arquetípicas de nuestra canción popular: el relato dramático de las circunstancias que, según los casos, se resuelve feliz o trágicamente. En esta ocasión, se trata del rescate de la temática del tango de las décadas del 20 y del 30, que sufrirán un proceso de recontextualización.

\section{Dos espectáculos, dos poéticas}

Tanto en Che Madam como en Metejón, guarda con el tango, el triángulo amoroso se narra, a través de uno o varios géneros y su transgresión.

Para el análisis de la peculiar narración de la arquetípica estructura que propone la poética de cada una de las puestas en escena, nos basaremos en las claves de actuación y los códigos de la escenografía. Cada puesta hace una propuesta escenográfica y de actuación diferente y ésto es lo que define su estética.

En Che Madam, cuyo texto dramático original se denomina "Muñeca brava", título que conceptualiza más adecuadamente el desarrollo y desenlace de la obra, el código de actuación del realismo asainetado define una estética en que la escenografía juega un rol, en cierto modo, contradictorio. El espectador debe realizar un tránsito no convencional -hiperrealista ${ }^{2}$ - por la extraescena realista (vestíbulo, cocina, baño y dormitorio de un inquilinato), para arribar, por contraste, a una platea y espacio escénico convencionales que representan un comedor y, alternativamente, una sala de baile, según las necesidades requeridas por la peripecia. La extraescena, en el transcurso de la intriga, se convertirá en un espacio escénico adicional, trabajado ambigüamente en profundidad y parcialmente velado al espectador.

La clave de actuación responde a lo cánones realistas del sainete. El ambiente total resulta también realista, acentuado por una utilería menor y mayor 
del mismo tenor. La iluminación es incidental, es decir, convencional-realista para el comedor/sala de baile, y atenuada y/o focalizada en los momentos de los monólogos y encuentros personales poéticos.

La música, en algunos momentos tiene una función realista revelando su fuente: un pasacasette, y en otros, incidentalmente acompaña la acción del baile o el encuentro personal.

Sin embargo, en consonancia con el comienzo, en el desenlace de Che Madam, el realismo no se presenta como un procedimiento estético teatral ortodoxo sainetero, sino que hay una transgresión a su poética presentando un epílogo insólito en relación a las leyes del género: el personaje femenino decide compartir su vida con los dos hombres y ellos, tácitamente, aceptan.

En Metejón... la escenografía narra metafóricamente la superposición y yuxtaposición de varios triángulos amorosos, en los que Laura es el personaje, eje o ángulo, sobre el que giran o pivotean todos los triángulos. Esta metáfora se manifiesta en la escenografía por medio de paredes espejadas que distorsionan las figuras reflejadas y las conflictivas relaciones de los personajes. Tres sillas -única utilería mayor- son cambiadas de ubicación alternativamente por los personajes, produciendo mutaciones del espacio único que, además es fragmentado por la proxemia, la posición relativa de los cuerpos de los personajes, creando ámbitos diferentes: el club, la cárcel, la habitación de José, que se conectan a través de un discurso que se desliza de un espacio a otro. Una escasa, significativa y polivalente utilería menor: un puñal que cuelga del techo, un guante rojo y papeles también rojos, completan un ámbito enrarecido por la peculiar iluminación.

En este ambiente de atmósfera onírica, acentuada por la modulación de la luz y el reflejo distorsionado de los cuerpos, la clave de actuación no responde totalmente a los cánones realistas sino que parece oscilar entre un realismo burgués, una especie de distanciamiento, y el grotesco; actuaciones inmersas en un discurso en el que hay rupturas y fragmentaciones del relato.

Durante el desarrollo y avance hacia el desenlace, los personajes masculinos, en un grotesco desenmascaramiento, van perdiendo su maquillaje payasesco para mostrar en sus rostros sus verdaderas motivaciones.

En Metejón..., la música y el canto son interpretados en vivo por un cuarteto de guitarras ("Las bordonas") y en la letras o el acompañamiento melódico -como en los orígenes del melodrama se refuerza y exalta el carácter dramático de las acciones y los vaivenes emocionales de los personajes. Esta música en vivo, y fuera del espacio escénico propiamente dicho, se contrapone 
-como elemento hiperrealista- a la atmósfera onírica que emana de la actuación y los otros lenguajes de la puesta en escena.

Este espectáculo, que propone una estética posmoderna, presenta una mezcla de códigos muy variados, de cruces de convenciones diversas que terminarán dando como resultado una estética de la mutación. Es decir que la propuesta de imágenes transgrede una estructura convencional: la del melodrama. De hecho, en el transcurso de Metejón... aparece con claridad una de las matrices melodramáticas (el triángulo amoroso), y en el desenlace la muerte del profesor, produce la restitución del orden, una de las características del melodrama: Armando (el profesor) provoca su propia muerte para expiar la culpa de haber instigado el crimen que dió lugar a la conformación de este triángulo amoroso.

En coincidencia con las opiniones de Bernardo Canal Feijóo, el tango y el teatro comparten en común un acto que se relaciona con el ritual. Este particular modo de relacionarse con lo "sagrado" encierra un "misterio" y quien lo baila se propone tratar de rozar ese misterio "original", es decir, conectarse con los aspectos fundantes de esa expresión artística. Este baile del abrazo aludiría a una pareja fundamental en la que se conjugan, en la esencia de la danza del tango, lo profano y lo místico.

En ambas puestas en escena, la "academia" de tango, el lugar donde se transmiten los saberes (salón de baile) es considerado como un "templo" y quiénes tienen la misión de "enseñar" el tango, se disponen, se invisten y ocupan el lugar del "oficiante" que impartirá sus conocimientos al iniciado, una vez que ha sido aceptado.

En Metejón..., Armando cumple el rol de un "patriarca" que imparte sus conocimientos sobre las sutilezas y "enigmas" que posee el tango. En esta oportunidad, el baile adquiere una dimensión existenciaria que impediría la muerte: un rito de renovación de la vida: "Bailen guachos... bailen así no me muero..."3 dice Armando, el profesor, mientras agoniza.

En Che Madam, Fortunato, al vestirse como "profesor", para "enseñar" a bailar el tango a Tito (futuro alumno), realiza una mise en scène -con Rosa, su ayudante- que va desde los atributos de la vestimenta (pollera ajustada y tacos altos para Rosa; peluquín, saco, sombrero y lengue para Fortunato) hasta las posturas y gestualidades típicas milongueras. El objetivo de este "ritual" es la introducción a esta danza desde la metacomprensión de lo "sagrado" que es el baile del tango, al que sólo unos pocos elegidos pueden acceder. 


\section{Conclusiones}

Lo descripto y analizado hasta aquí nos sugiere las siguientes reflexiones, desde lo particular a lo general: la narrativa del tango en el teatro, desde una perspectiva posmoderna, produce en Metejón... un ahondamiento del melodrama, al estilo Ripstein, deslizado hacia el grotesco, transgrediendo la propuesta estética con un final moderno, convencional. Mientras que Che Madam, con una propuesta dramática convencional, transgrede las leyes del género sainetero arribando a un desenlace insólito, no convencional, neosainetero o, quizás, posmoderno. Es decir, que en ambos casos, las matrices del género y/o estéticas propuestas son transgredidas a través de una hibridación.

En definitiva, y para concluir, las imágenes narrativas del tango en el teatro del nuevo siglo son producto de la recontextualización, la hibridación de las imágenes producidas en el transcurso de siglos pasados y el desplazamiento de las fronteras entre los genéros. Es decir, la mezcla de lo viejo, lo arcaico, la ritualidad, y lo nuevo: modelos genéricos fragmentados, trastocados y transgredidos.

\section{Referencias}

CANAL-FEIJOÓ, Bernardo, El canto de la ciudad, Albino y asociados editores, Buenos Aires, 1980.

GUBERN, Roman, Mensajes icónicos en la cultura de masas, Editorial Lumen, Barcelona, 1974.

HALAC, Ricardo, Teatro, Tomo V, Ediciones Corregidor, Buenos Aires, 2000. Martín-Barbero, Jesús, De los medios a las mediaciones, Ed. Gustavo Gili, México, 1987.

RIVERA, Jorge y Ford, Anibal, Las literaturas marginales, Capítulo Universal, CEAL, Buenos Aires, 1971.

ROMANO, Eduardo, Las letras del tango, Ed. Fundación Ross, Rosario, 1995.

\section{Notas}

1 Jorge Rivera y Aníbal Ford, “La canción popular”, en Las literaturas marginales,pág. 89.

${ }^{2}$ Hiperrealismo: no intentaremos definir este concepto en teatro sino que lo ejemplificamos por analogía con la plástica y como mo contraste en el contexto de la obra.

${ }^{3}$ Citado de Metejón, guarda con el tango de Ricardo Halac, pág. 91. 